\title{
Is the Measurement of Cerebral Microembolic Signals a Good Surrogate Marker for Evaluating the Efficacy of Antiplatelet Agents in the Prevention of Stroke?
}

\author{
K.S. Lawrence Wong \\ Division of Neurology, Department of Medicine and Therapeutics, The Chinese University of Hong Kong, \\ The Prince of Wales Hospital, Hong Kong, China
}

\section{Key Words}

Antiplatelet therapy · Atherothrombosis - Cerebral microembolic signals $\cdot$ Clopidogrel $\cdot$ Stroke

\begin{abstract}
Stroke is difficult to treat with few treatment options. Until such time as appropriate therapeutic regimens are established, prevention, both in the primary and in the secondary setting, is of paramount importance. Evaluation of pharmacological agents for the prevention of stroke in conventional clinical studies has the advantage that the outcome parameter is a direct measure of efficacy, and the disadvantage that many patients must be recruited and many evaluations performed over an extended period to provide adequate statistical power, making such studies lengthy and costly. Measurement of cerebral microembolic signals (MES) using transcranial Doppler ultrasonography has been proposed as a useful surrogate end point to investigate new antiplatelet agents and to evaluate further the benefits of existing antiplatelet therapies. MES measurements may provide a means of more directly evaluating the pharmacological activity of an antiplatelet agent. However, does measurement of MES accurately predict efficacy in stroke prevention? This review evaluates recent studies where the relationship between MES and cerebral ischaemic events has been explored and studies where the effects of antiplatelet agents on MES rates have been investigated.
\end{abstract}

Overall, there is a growing body of evidence to suggest that MES may be used as a surrogate marker for cerebral infarction and clinical events, thus allowing quick appraisal of the efficacy of antiplatelet agents. Studies currently in progress should provide further insight into the value of the measurement of MES in clinical studies in stroke prevention.

Copyright (C) 2005 S. Karger AG, Basel

\section{Introduction}

Stroke is a major cause of death and disability in the world. However, despite a relentless search over the last few years for efficacious treatments, stroke remains difficult to treat and frequently results in long-term disability with attendant social and economic implications [1]. Currently the only approved treatment for acute strokes is tissue plasminogen activator (tPA). The vast majority of stroke sufferers are not, however, suitable for tPA treatment as tPA must be administered within $3 \mathrm{~h}$ of the onset of symptoms and this condition is often not met. Clearly, until such time as appropriate therapeutic regimens are established, prevention, both in the primary and in the secondary setting, is of paramount importance.

Most strokes are ischaemic in nature and are a consequence of underlying atherothrombotic disease. Evidence that antiplatelet agents can reduce the risk of stroke has emerged from a number of clinical studies. The Anti-

\section{KARGER}

Fax +4161306 1234 E-Mail karger@karger.ch www.karger.com
(C) 2005 S. Karger AG, Basel 0014-3022/05/0533-0132\$22.00/0

Accessible online at: www.karger.com/ene
K.S. Lawrence Wong

Division of Neurology, Department of Medicine and Therapeutics

The Chinese University of Hong Kong, The Prince of Wales Hospital

Hong Kong (China)

Tel. +852 2632 3173, Fax +852 2637 3852, E-Mail ks-wong@cuhk.edu.hk 
thrombotic Trialists' Collaboration [2] summarized the evidence for the efficacy of antiplatelet therapy in reducing the risk of stroke in high-risk patients. This evidence included the results of two large well-controlled trials: the European Stroke Prevention Study 2 (ESPS2) [3] and Clopidogrel versus Aspirin in Patients at Risk of Ischemic Events (CAPRIE) [4]. ESPS2 demonstrated that both acetylsalicylic acid (ASA) and sustained-release dipyridamole produce a significant risk reduction in stroke and transient ischaemic attack (TIA) compared with placebo in patients who had already survived a stroke or TIA, while the two treatments combined have an additive effect. The CAPRIE study [4] showed that clopidogrel treatment of patients with atherothrombosis is more effective than treatment with ASA in reducing the combined risk of ischaemic stroke, myocardial infarction or vascular death. Subsequent studies such as the Clopidogrel in Unstable Angina to prevent Recurrent Events [5] trial and the Clopidogrel for Reduction of Events During Observation [6] trial have provided convincing evidence of the additive effects of treatment with clopidogrel in addition to ASA.

Evaluation of pharmacological agents for the prevention of stroke in conventional clinical studies, such as ESPS2 and CAPRIE, has the great advantage that the outcome parameter is a direct measure of efficacy. However, clinical trials of this kind are not without their disadvantages. Studies need to recruit many patients, and evaluations need to be performed over an extended period to provide adequate statistical power, resulting in studies that are costly to perform and take many years to accomplish. Furthermore, studies with cardiovascular and cerebrovascular end points as efficacy outcome parameters do not permit the evaluation of the direct pharmacological activity of the therapy.

Measurement of microembolic signals (MES) using transcranial Doppler ultrasonography (TCD) has been proposed as a useful (simple, rapid) technique for determining the presence of microemboli moving through cerebral arteries, and therefore as a surrogate end point to investigate the value of new antiplatelet agents in the treatment of stroke and to evaluate further the benefits of existing antiplatelet therapies. MES can be a consequence of artery-to-artery embolism in patients with large artery disease (carotid or middle cerebral artery stenosis) and drugs that reduce MES may prevent stroke by preventing artery-to-artery embolism. Consequently, measurement of MES may provide a means of more directly evaluating the pharmacological activity of an antiplatelet agent.

This review will evaluate recent studies, where the relationship between MES and cerebral ischaemic events has been explored and studies where the effects of antiplatelet agents on MES rates have been investigated.

\section{Microemboli and MES}

Microemboli in the cerebral circulation can have a number of origins, including sources such as atherothrombotic lesions of the carotid arteries and cardiac sources such as severe ventricular dysfunction, atrial fibrillation and valvular disease [7]. Microemboli also appear to be commonly seen during interventional procedures such as cerebral and coronary angiography, carotid angioplasty, carotid endartectomy and cardiopulmonary bypass [8]. Microemboli can be caused by platelet aggregation consequent to atherosclerotic plaque rupture, or may result from shear stress due to vessel narrowing by vascular stenosis $[9,10]$.

The detection of arterial emboli using TCD is a wellestablished technique, which is simple, non-invasive, inexpensive, sensitive and specific. Circulating cerebral microemboli - which may be of thrombus, platelet, atheroma or air bubble origin depending on the clinical situation - passing through the sample volume of an ultrasound probe cause a unidirectional intensity increase within the Doppler frequency spectrum (fig. 1), which can be acoustically identified by the operator $[8,11-14]$. Recordings of the signal of at least $30 \mathrm{~min}$ to $1 \mathrm{~h}$ are usually assessed by an independent observer, blinded to the patient history.

One of the major drawbacks of TCD is that trained personnel are required to carry out the procedure and interpret the results. Furthermore, many old patients may have poor acoustic bone window, and patients need to be monitored for prolonged periods of time. Recently, Mackinnon et al. [15] have published a paper describing a device that permits ambulatory monitoring. Technical improvements of this kind will significantly increase the utility of the technique.

Another major problem of TCD is that many microemboli are gaseous, rather than solid, in nature and are produced by cavitation at mechanical heart valves or other processes. These two types of microemboli produce very similar signals during TCD, which has historically made them very difficult to differentiate [14]. As the clinical implications of the presence of the two types are quite different, some physicians have disputed the ability of MES to predict recurrent ischaemic events. This problem will hopefully soon be solved with the ongoing development of better equipment and automated analysis, which 
Fig. 1. An example of microembolic signal detected in the middle cerebral artery. There is a change in the frequency detected by TCD, which produces a color change on the signal.
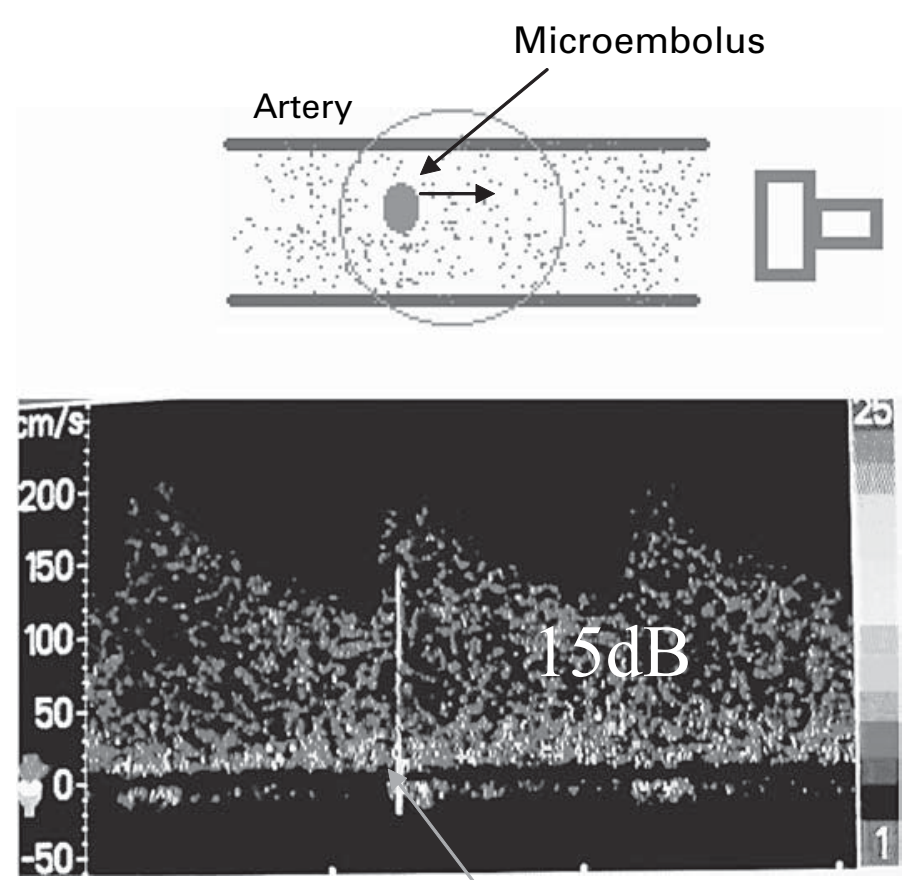

Detection of the microembolus leads to a change in signal frequency already achieves better than $80 \%$ sensitivity and specificity for solid emboli [16].

\section{Relationship between MES and the Risk of Stroke}

The association between the presence of MES and the risk of ischaemic cerebral events has been studied by a number of researchers. Table 1 lists the studies discussed in this article, together with details of the study design, etc. Since all of the patients enrolled had proven atherosclerosis, it is reasonable to assume that most MES detected would have been caused by solid emboli from vascular lesions.

Siebler et al. [17] were amongst the first groups to investigate the relationship. They measured MES frequency in 64 patients with unilateral $70-90 \%$ internal carotid artery stenosis and no history of retinal or cerebral ischaemic symptoms. Five patients developed ischaemic symptoms during the follow-up period (mean duration 72 weeks). A microembolic rate of $\geq 2$ per hour in the ipsilateral middle cerebral artery was associated with a sig- nificantly increased risk of developing cerebral ischaemia [odds ratio $(\mathrm{OR})=31,95 \%$ confidence interval $(\mathrm{CI})=$ 3-302, $\mathrm{p}=0.005$ ].

The relationship between MES frequency and risk of cerebral ischaemia in patients undergoing carotid endartectomy was studied by Levi et al. [18]. They measured MES in 59 patients intra- and post-operatively. MES were detectable in $69 \%$ of patients during the first postoperative hour with a mean frequency of 19 counts per hour [standard error of the mean $(\mathrm{SEM}) \pm 4.5$ ]. There was a clear association between MES counts $>50$ per hour ( 7 cases) and the development of ischaemic stroke (3 cases) and TIA (two cases) in the territory of the insonated middle cerebral artery during the monitoring period $\left(\chi^{2}=\right.$ $45.9, \mathrm{p}<0.0001)$. The positive predictive value for cerebral ischaemia of counts $>50$ per hour was 0.71 .

Valton et al. [19] investigated the incidence of early ischaemic recurrence (EIR) in 73 patients with strokes or TIAs that were considered to be of carotid origin on the basis of symptomatic presentation and lack of confounding co-morbid conditions. Patients were monitored for MES within 7 days of the onset of symptoms and followed-up for the duration of their hospital stay [mean \pm 
Table 1. Summary of studies showing association between MES and risk of ischaemic events

\begin{tabular}{|c|c|c|c|c|}
\hline Study & Study design & Condition & Study end points & Outcome \\
\hline Siebler et al., 1995 [17] & $\begin{array}{l}\text { prospective, blinded off-line } \\
\text { assessment, } \mathrm{n}=64\end{array}$ & $\begin{array}{l}\text { asymptomatic carotid } \\
\text { stenosis }\end{array}$ & ischaemic symptom (stroke/TIA) & $\begin{array}{l}\mathrm{MES} \geq 2 / \mathrm{h} \rightarrow \mathrm{OR}=31 \\
(95 \% \mathrm{CI}=3-302, \mathrm{p}=0.005)\end{array}$ \\
\hline Levi et al., 1997 [18] & $\begin{array}{l}\text { prospective, blinded off-line } \\
\text { assessment, } \mathrm{n}=65\end{array}$ & carotid endarterectomy & $\begin{array}{l}\text { any focal ischaemic neurological deficit } \\
\text { and/or death } \leq 30 \text { days after operation }\end{array}$ & $\begin{array}{l}\text { MES }>50 / \mathrm{h} \rightarrow \text { greater risk of } \\
\text { stroke/TIA }(\mathrm{p}<0.0001)\end{array}$ \\
\hline Valton et al., 1998 [19] & $\begin{array}{l}\text { prospective, blinded off-line } \\
\text { assessment, } \mathrm{n}=73\end{array}$ & $\begin{array}{l}\text { symptomatic carotid } \\
\text { stenosis }\end{array}$ & EIR (stroke/TIA) & $\begin{array}{l}\text { presence of } \mathrm{MES} \rightarrow \mathrm{RR}=8.7 \\
(95 \% \mathrm{CI}=2-38.2, \mathrm{p}=0.015)\end{array}$ \\
\hline $\begin{array}{l}\text { Molloy and Markus, } 1999 \\
\text { [20] }\end{array}$ & $\begin{array}{l}\text { prospective, blinded off-line } \\
\text { assessment, } \mathrm{n}=111\end{array}$ & carotid stenosis & $\begin{array}{l}\text { stroke, TIA, death, carotid } \\
\text { endarterectomy or angioplasty }\end{array}$ & $\begin{array}{l}\text { MES predictive of stroke/TIA } \\
\text { in symptomatic }(\mathrm{p}=0.02) \\
\text { and asymptomatic }(\mathrm{p}=0.007) \\
\text { patients }\end{array}$ \\
\hline Babikian et al., 1997 [21] & $\begin{array}{l}\text { retrospective, unblinded, } \\
\mathrm{n}=302\end{array}$ & carotid stenosis & $\begin{array}{l}\text { new or recurrent cerebral ischaemic } \\
\text { event }\end{array}$ & $\begin{array}{l}\text { more EIRs observed in MES- } \\
\text { positive arteries ( } 9 \text { of } 10)\end{array}$ \\
\hline Wong et al., 2002 [22] & $\begin{array}{l}\text { prospective, blinded off-line } \\
\text { assessment, } \mathrm{n}=30\end{array}$ & $\begin{array}{l}\text { middle cerebral carotid } \\
\text { artery stenosis }\end{array}$ & acute cerebral infarct & $\begin{array}{l}\text { MES predicts acute infarcts } \\
\text { on DWI }\left(\mathrm{R}^{2}=0.475\right. \\
\mathrm{p}<0.001)\end{array}$ \\
\hline Gao et al., 2004 [23] & $\begin{array}{l}\text { prospective, blinded off-line } \\
\text { assessment, } \mathrm{n}=114\end{array}$ & $\begin{array}{l}\text { middle cerebral carotid } \\
\text { artery stenosis }\end{array}$ & further ischaemic event (stroke/TIA) & $\begin{array}{l}\text { presence of } \mathrm{MES} \rightarrow \mathrm{OR}= \\
8.45(95 \% \mathrm{CI}=1.69-42.22 \\
\mathrm{p}=0.01)\end{array}$ \\
\hline
\end{tabular}

MES = Microembolic signals; TIA = transient ischaemic attack; EIR = early ischaemic recurrence; OR = odds ratio; $\mathrm{RR}=$ relative risk.

standard deviation (SD) follow-up $=10 \pm 8$ days]. Eight patients had an EIR during the follow-up period (two strokes and six TIAs) -5 occurred in the 15 patients with MES (33\%), but only 3 in the 58 patients without MES $(5 \%, \mathrm{p}=0.008)$. Further analysis showed that the presence of MES is a significant independent predictor of EIR in patients with carotid stroke or TIA (relative risk $=8.7$, 95\% CI $=2-38.2, \mathrm{p}=0.015$ ).

Molloy and Markus [20] looked at the correlation between the frequency of MES and subsequent incidence of stroke or TIA in 111 patients with $>60 \%$ carotid stenosis (measured by Duplex ultrasound) and no obvious source of cardiac emboli. Just over a third of the patients were asymptomatic and the remainder had had symptoms in the territory of the stenosed artery within the previous 12 months. MES were detected in 41 subjects. The presence of MES was predictive of TIA and stroke risk during follow-up in both symptomatic ( $p=0.02)$ and asymptomatic patients $(p=0.007)$, while MES were more common in subjects with plaque ulceration with a relative risk of $4.94(95 \% \mathrm{CI}=1.23-19.84, \mathrm{p}=0.025)$.

In a retrospective study, Babikian et al. [21] examined the relationship between the presence of MES along the internal carotid or basilar artery territories and the risk of experiencing a recurrent cerebral or retinal ischaemic event. Out of 229 patients with cerebrovascular disease, but no cardiac embolic sources, MES were detected in 61 out of 310 affected arteries and were observed significantly more often in symptomatic $(28.6 \%)$ compared with asymptomatic $(12.4 \%)$ vessels (relative risk $=2.3$, $95 \% \mathrm{CI}=1.4-3.7, \mathrm{p}<0.001)$. Out of 10 recurrent ischaemic events that occurred during a median follow-up of 8 days after MES measurement, 9 occurred in the territories of MES-positive arteries, but only 1 in the territory of an MES-negative artery. Furthermore, MES were seen significantly more frequently in arteries with lesions causing more than $70 \%$ stenosis or occlusion than in those with a degree of stenosis $<70 \%(\mathrm{p}=0.016)$.

In a study to examine the mechanism of acute cerebral infarction in patients with middle cerebral artery stenosis, we found that MES frequency predicted the number of acute cerebral infarcts as measured by diffusion weighted imaging (DWI) [22]. Of the 30 patients who entered the study, 15 had single and 15 multiple infarcts. MES were detected in 10 patients; 9 with multiple infarcts and 1 with a single infarct. The number of MES predicted the number of acute infarcts on DWI (linear regression, adjusted $\mathrm{R}^{2}=0.475, \mathrm{p}<0.001$ ). A follow-up study involving an additional 114 patients found that MES was more common in patients with severe stenosis $(48 \%)$ than in those with mild-to-moderate stenosis $(15 \%, \mathrm{p}=0.02$, Pearson $\chi^{2}$ ). In addition, MES was a predictor for further 
ischaemic stroke or TIA (adjusted OR $=8.45,95 \% \mathrm{CI}=$ 1.69-42.22, $\mathrm{p}=0.01$ ) [23].

Overall, these studies provide a wealth of data to support the premise that MES are a surrogate marker for stroke and TIA risk. The presence of MES also appears to correlate with the presence and degree of severity of the arterial stenotic lesion. It should be noted that the confidence limits of the results reported above are very wide, demonstrating the need for larger, better powered studies.

\section{Use of MES Measurements in Evaluating Antiplatelet Therapies for Stroke Prevention}

A number of relatively small studies have investigated the relationship between antiplatelet therapy and MES frequency. These are summarized in table 2, together with details of the study design and endpoints. Most studies have looked at the effects of ASA on MES frequency, although recent studies have investigated the effects of the glycoprotein IIb/IIIa receptor antagonist tirofiban, and of the adenosine diphosphate (ADP) receptor antagonist clopidogrel. Studies have also been carried out on the investigational products $L$-arginine and S-nitrosoglutathione (GSNO). Both substances have been proposed as having antiplatelet activity; $L$-arginine on the basis that it reduces platelet aggregation and adhesion in vitro and GSNO on the basis that it is a physiological nitric oxide donor.

Goertler et al. [24] investigated the effects of intravenous ASA treatment on MES in 9 patients who had had a recent stroke or TIA, considered to be middle cerebral arterioembolic in origin, within the previous 12 days. The frequency of MES detection decreased significantly in 7 of 9 patients following the administration of ASA, from a mean signal rate per hour of 25.1 to a mean value of 6.4 , $30 \mathrm{~min}$ after drug administration. One patient did not respond to treatment and only a minor and transient effect was seen in another, although this latter patient was already receiving ASA at the time of study entry. Interestingly, MES were only detected ipsilateral to the symptomatic stenoses with no signals detected in the contralateral middle cerebral arteries.

Another study from this group published in 2001 [25] investigated the frequency of MES in 74 patients with amaurosis fugax, TIA or minor stroke attributable to the territory of the middle cerebral artery and without evidence of cardiac involvement. MES were detected in 19 of $26(73 \%)$ patients who did not receive antiplatelet med- ication, 9 of $23(39 \%)$ who received ASA since experiencing the ischaemic event and 10 of $25(40 \%)$ who were already receiving ASA before experiencing the ischaemic event. Multivariate analysis indicated an association between the absence of medication with ASA and the occurrence of MES $(\mathrm{OR}=7.1,95 \% \mathrm{CI}=1.6-31.4, \mathrm{p}=$ 0.01 ).

Goertler et al. [26] further studied this relationship in 86 patients with a non-disabling arterioembolic ischaemic event in the anterior circulation within the previous 30 days and a medium- or high-grade stenosis ( $\geq 50 \%)$ of the ipsilateral carotid or middle cerebral artery. Patients underwent TCD monitoring on admission and antithrombotic treatment commenced. Patients in whom embolic signals were detected underwent a second monitoring within 4 days and were then followed up for 6 weeks. MES were detected at admission in 44 patients, while only 25 were MES positive at the second monitoring. During follow-up, 6 ischaemic events (2 strokes, 3 TIAs, 1 amaurosis fugax) occurred in the 25 patients with persisting MES, compared with none in the 19 patients in whom signals had ceased by the second monitoring. The decrease in MES was found to be significantly associated with the administration of antiplatelet agents $(\mathrm{p}<$ $0.001)$.

The effect of tirofiban in reducing MES has been studied in 24 patients with recent cerebral or retinal embolism of arterial origin and without obvious source of cardiac emboli [27]. In this study, patients who had an MES rate of $>6$ per hour received tirofiban by infusion at a dose of $0.4 \mu \mathrm{g} / \mathrm{kg}$ body weight for $30 \mathrm{~min}$ followed by continuous infusion at a dose of $0.1 \mu \mathrm{g} / \mathrm{kg}$ body weight together with intravenous unfractionated heparin. Within $24 \mathrm{~h}$ of initiation of the tirofiban infusion, the MES frequency decreased from a median of 38 (range 9-324) per hour to 0 in all patients. The inhibitory effect of tirofiban on MES rate was reversible; on cessation of therapy, the rate of MES increased significantly to a median value of 13.5 (range 0-35).

The effects of clopidogrel treatment on top of ASA in reducing MES has been investigated in 8 patients ( 5 with acute ischaemic stroke and 3 with TIA) with extracranial stenosis diagnosed by duplex ultrasound or intracranial artery stenosis identified by TCD [28]. All patients were receiving ASA therapy at the time of study entry, with 1 patient also receiving dipyramidole. After study entry, patients received clopidogrel $75 \mathrm{mg}$ daily on top of their ASA. The median number of MES at baseline was 8 (range 3-51). MES measurements carried out on days 3-7 of dual therapy showed a significant reduction in sig- 
Table 2. Summary of design and endpoints of studies evaluating effect of anti-platelet therapy on MES

\begin{tabular}{|c|c|c|c|c|c|}
\hline Study & Study design & Condition & Study arms & Assessment & Outcome \\
\hline $\begin{array}{l}\text { Goertler } \\
\text { et al., } 1999 \text { [24] }\end{array}$ & $\begin{array}{l}\text { single arm, } \\
\mathrm{n}=9\end{array}$ & $\begin{array}{l}\text { symptomatic carotid } \\
\text { stenosis; symptoms } 0-12 \\
\text { days prior to initiation }\end{array}$ & $\begin{array}{l}\text { bolus ASA } 500 \text { mg i.v.; oral } \\
\text { ASA } 300 \text { mg/day next day } \\
\text { onwards }\end{array}$ & $\begin{array}{l}\text { TCD } 2.5 \mathrm{~h} \text { after bolus; } \\
\text { additional assessment ( } 1 \mathrm{~h}) \\
\text { within } 2 \text { days }\end{array}$ & $\begin{array}{l}\text { MES reduced from } 25.1 \\
\text { to } 6.4 \text { per hour }\end{array}$ \\
\hline $\begin{array}{l}\text { Goertler } \\
\text { et al., } 2001 \text { [25] }\end{array}$ & $\begin{array}{l}\text { unblinded, } \\
\text { dual arm, } \\
\mathrm{n}=74\end{array}$ & $\begin{array}{l}\text { symptomatic carotid } \\
\text { stenosis }\end{array}$ & $\begin{array}{l}\text { ASA or no antiplatelet } \\
\text { therapy during TCD }\end{array}$ & $\begin{array}{l}\text { 1-hour TCD immediately after } \\
\text { patient admission/presentation }\end{array}$ & $\begin{array}{l}\text { detection of MES } \\
\text { reduced from } 73 \text { to } 40 \% \\
\text { of patients }\end{array}$ \\
\hline $\begin{array}{l}\text { Goertler } \\
\text { et al., } 2002 \text { [26] }\end{array}$ & $\begin{array}{l}\text { single arm, } \\
\mathrm{n}=86\end{array}$ & $\begin{array}{l}\text { arterioembolic stroke, } \\
\text { with } \geq 50 \% \text { carotid } \\
\text { stenosis }\end{array}$ & $\begin{array}{l}\text { antithrombotic therapy } \\
\text { initiated after } 1 \mathrm{~h} \text { TCD } \\
\text { after admission }\end{array}$ & $\begin{array}{l}\text { 1-hour TCD within } 4 \text { days; } \\
\text { occurrence of cerebral } \\
\text { ischaemic events after } 6 \text { weeks }\end{array}$ & $\begin{array}{l}\text { MES decreased } \\
\text { significantly by } \\
\text { antiplatelets }(\mathrm{p}<0.001)\end{array}$ \\
\hline $\begin{array}{l}\text { Junghans and } \\
\text { Siebler, } \\
2003 \text { [27] }\end{array}$ & $\begin{array}{l}\text { single-arm, blinded } \\
\text { off-line MES } \\
\text { assessment, } n=24\end{array}$ & $\begin{array}{l}\text { recent symptoms of } \\
\text { ischaemic event }\end{array}$ & $\begin{array}{l}\text { bolus tirofiban } 0.4 \mu \mathrm{g} / \mathrm{kg} / \mathrm{min} \\
\text { for } 30 \mathrm{~min} \text {, followed by } \\
0.1 \mu \mathrm{g} / \mathrm{kg} / \mathrm{min} \text { cont. inf. }\end{array}$ & $\begin{array}{l}20-30 \text { min TCD before } \\
\text { tirofiban, at end of cont. inf., } \\
\text { and } \geq 2 \text { h after infusion }\end{array}$ & $\begin{array}{l}\text { MES frequency reduced } \\
\text { from median } 38(9-324) \\
\text { to } 0 \text { in all patients }\end{array}$ \\
\hline $\begin{array}{l}\text { Esagunde et al., } \\
\text { in press [28] }\end{array}$ & single arm, $\mathrm{n}=8$ & $\begin{array}{l}\text { symptomatic carotid } \\
\text { stenosis }\end{array}$ & $\begin{array}{l}75 \mathrm{mg} \text { clopidogrel added to } \\
\text { ongoing ASA therapy }\end{array}$ & $\begin{array}{l}\text { Repeat TCD between days 3-7 } \\
\text { and after } 2 \text { months }\end{array}$ & $\begin{array}{l}\text { MES reduced from } \\
\text { median } 8(3-51) \text { to } \\
\text { median } 0.5(0-12) \text { after } \\
7 \text { days }(\mathrm{p}=0.012) \\
\text { no emboli observed at } \\
2 \text { months }\end{array}$ \\
\hline $\begin{array}{l}\text { Payne } \\
\text { et al., } 2004 \text { [29] }\end{array}$ & $\begin{array}{l}\text { dual-arm, } \\
\text { double-blinded, } \\
\text { randomized, } \\
\text { placebo-controlled, } \\
\text { independent MES } \\
\text { assessment, } \mathrm{n}=100\end{array}$ & carotid endarterectomy & $\begin{array}{l}75 \mathrm{mg} \text { clopidogrel or placebo } \\
\text { night before surgery; all } \\
\text { patients on long-term ASA } \\
150 \mathrm{mg}\end{array}$ & $\mathrm{TCD} \leq 3 \mathrm{~h}$ after surgery & $\begin{array}{l}\text { MES decreased by } \\
\text { clopidogrel over placebo } \\
(\mathrm{OR}=10.23,95 \% \mathrm{CI}= \\
1.3-83.3, \mathrm{p}=0.01)\end{array}$ \\
\hline $\begin{array}{l}\text { Kaposzta } \\
\text { et al., } 2001[30]\end{array}$ & $\begin{array}{l}\text { double-blind, } \\
\text { randomized, } \\
\text { placebo-controlled, } \\
\text { blinded } \\
\text { off-line MES } \\
\text { assessment, } \mathrm{n}=42\end{array}$ & carotid endarterectomy & $\begin{array}{l}\text { GSNO } 2.2-4.4 \mathrm{nmol} / \mathrm{kg} / \mathrm{min} \\
\text { i.v. or } L \text {-arginine } 30 \mathrm{~g} \text { i.v. or } \\
\text { saline i.v. given } 30 \mathrm{~min} \text { after } \\
\text { surgery; all patients given } \\
\text { ASA and heparin }\end{array}$ & $\begin{array}{l}\text { TCD for } 1 \mathrm{~h} \leq 24 \mathrm{~h} \text { before } \\
\text { surgery, for } 4 \mathrm{~h} 30 \mathrm{~min} \text { after } \\
\text { surgery, and for } 1 \mathrm{~h} 6 \text { and } 24 \mathrm{~h} \\
\text { after surgery }\end{array}$ & $\begin{array}{l}\text { MES reduced by both } \\
\text { active agents at } 4 \text { and } \\
24 \mathrm{~h}(\mathrm{p}<0.001)\end{array}$ \\
\hline $\begin{array}{l}\text { Kaposzta } \\
\text { et al., } 2002 \text { [31] }\end{array}$ & $\begin{array}{l}\text { double-blind, } \\
\text { randomized, } \\
\text { placebo-controlled, } \\
\text { blinded } \\
\text { off-line MES } \\
\text { assessment, } \mathrm{n}=16\end{array}$ & $\begin{array}{l}\text { angioplasty/carotid } \\
\text { artery stenting }\end{array}$ & $\begin{array}{l}\text { GSNO } 2.2-4.4 \mathrm{nmol} / \mathrm{kg} / \mathrm{min} \\
\text { i.v. or saline i.v. given } \\
30 \text { min after surgery; } \\
\text { all patients given ASA }\end{array}$ & $\begin{array}{l}\text { TCD for } 1 \mathrm{~h} \text { before treatment, } \\
\text { for } 3 \mathrm{~h} \text { on initiation of therapy, } \\
\text { and } 1 \mathrm{~h} 6 \text { and } 24 \mathrm{~h} \text { after } \\
\text { initiation }\end{array}$ & $\begin{array}{l}\text { MES reduced by GSNO } \\
\text { at } 3 \mathrm{~h}(95 \%, \mathrm{p}=0.007) \\
\text { and } 6 \mathrm{~h}(100 \%, \mathrm{p}=0.01)\end{array}$ \\
\hline $\begin{array}{l}\text { Kaposzta } \\
\text { et al., } 2002 \text { [32] }\end{array}$ & $\begin{array}{l}\text { double-blind, } \\
\text { randomized, } \\
\text { placebo-controlled, } \\
\text { blinded } \\
\text { off-line MES } \\
\text { assessment, } \mathrm{n}=20\end{array}$ & $\begin{array}{l}\text { symptomatic carotid } \\
\text { stenosis }\end{array}$ & $\begin{array}{l}\text { GSNO } 2.2-4.4 \mathrm{nmol} / \mathrm{kg} / \mathrm{min} \\
\text { i.v. or saline i.v. given } \\
30 \text { min after surgery; } \\
\text { all patients given ASA }\end{array}$ & $\begin{array}{l}\text { TCD for } 1 \mathrm{~h} \text { before treatment, } \\
\text { for } 3 \mathrm{~h} \text { on initiation of therapy, } \\
\text { and } 1 \mathrm{~h} 6 \text { and } 24 \mathrm{~h} \text { after } \\
\text { initiation }\end{array}$ & $\begin{array}{l}\text { MES reduced by GSNO } \\
\text { at } 3 \mathrm{~h}(84 \%, \mathrm{p}<0.0001) \text {, } \\
6 \mathrm{~h}(95 \%, \mathrm{p}=0.003) \text { and } \\
24 \mathrm{~h}(100 \%, \mathrm{p}<0.0001)\end{array}$ \\
\hline $\begin{array}{l}\text { Markus } \\
\text { and Ringelstein, } \\
2004[33]\end{array}$ & $\begin{array}{l}\text { multicenter, } \\
\text { randomized, } \\
\text { double-blind, } \\
\text { two-parallel groups, } \\
\text { blinded off-line MES } \\
\text { assessment, } \mathrm{n}=107\end{array}$ & $\begin{array}{l}\text { symptomatic carotid } \\
\text { stenosis/TIA/minor } \\
\text { stroke }\end{array}$ & $\begin{array}{l}\text { clopidogrel ( } 300 \mathrm{mg} \mathrm{d} 1 \text {, } \\
75 \mathrm{mg} \mathrm{d} 2-7 \text { ) or placebo; all } \\
\text { patients given ASA } 75 \mathrm{mg} \\
\mathrm{d} 2-7\end{array}$ & $1 \mathrm{~h}$ TCD on days 0,1 and 7 & $\begin{array}{l}\text { MES decreased by } \\
\text { clopidogrel/ASA over } \\
\text { ASA from } 72.5 \text { to } 45 \% \\
(\mathrm{RR}=37.7 \%, \mathrm{p}=0.01)\end{array}$ \\
\hline
\end{tabular}

MES = Microembolic signals; ASA = acetylsalicylic acid; TCD = transcranial Doppler ultrasonography 
nal frequency [median $=0.5($ range $0-12), p=0.012]$ with a complete cessation of MES in 4 patients. Another study assessed the effect of clopidogrel combined with aspirin on platelet response to ADP and postoperative MES in carotid endarterectomy (CEA) patients. The number of emboli detected by TCD within $3 \mathrm{~h}$ of CEA were independently quantified and the results displayed a significant decrease in MES for clopidogrel over placebo $(\mathrm{OR}=$ $10.23,95 \% \mathrm{CI}=1.3-83.3, \mathrm{p}=0.01)$. Clopidogrel also significantly reduced platelet ADP response compared with placebo $(8.8 \%, \mathrm{p}<0.05)$ [29].

Recently, a number of studies have used the measurement of MES as an experimental tool to assess the potential efficacy of $L$-arginine and GSNO in stroke prevention. In the first study [30], 42 patients undergoing CEA were treated postoperatively with intravenous $L$-arginine, GSNO or placebo for $90 \mathrm{~min}$, and MES measurements were made. MES were significantly reduced in the $L$-arginine and GSNO groups compared with the placebo group ( $p<0.001$ in both cases) at $4 \mathrm{~h}$ and $24 \mathrm{~h}$ after treatment. In a second study [31] in 16 patients undergoing carotid angioplasty and stenting for symptomatic $\geq 70 \%$ internal carotid artery stenosis, GSNO treatment resulted in a rapid reduction in the frequency of embolic signals of $95 \%$ at $3 \mathrm{~h}$ and $100 \%$ at $6 \mathrm{~h}$ ( $\mathrm{p}=0.007$ and $\mathrm{p}=0.01$ vs. placebo, respectively). In a third study [32] involving 20 patients with $\geq 50 \%$ internal carotid artery stenosis and with $\geq 3$ embolic signals detected during a half-hour screening, MES were measured following treatment with either GSNO ( $4.4 \mathrm{mmol} / \mathrm{kg}$ per min) or placebo for $90 \mathrm{~min}$. GSNO resulted in a rapid reduction in the frequency of embolic signals of $84 \%$ at $3 \mathrm{~h}, 95 \%$ at $6 \mathrm{~h}$ and $100 \%$ at $24 \mathrm{~h}(\mathrm{p}<0.0001, \mathrm{p}=0.003$ and $\mathrm{p}<0.0001$ vs. placebo, respectively).

The Clopidogrel and Aspirin for Reduction of Emboli in Symptomatic Carotid Stenosis study was designed to investigate the effects of clopidogrel in addition to ASA compared with the effects of ASA alone on the incidence of cerebral MES in patients with symptomatic (TIA or stroke within past 3 months) carotid artery stenosis $(>50 \%)$. Platelet aggregation, activation and platelet-dependent thrombin generation were also investigated. Initial results have shown that the incidence of MES was reduced from $72.5 \%$ in the placebo group to $45 \%$ in the clopidogrel group (relative risk reduction $=37.7 \%, \mathrm{p}=$ 0.01). Furthermore, the mean rate of embolization (expressed as a percentage of baseline) was reduced compared with placebo at day 1 from 59.3 to $22.1 \%$ (p < $0.001)$ and at day 7 from 37.1 to $14.4 \%(p=0.001)$ [33].

Some of the above studies were not placebo controlled. This is important as MES in acutely symptomatic pa- tients is known to fall in the days after an event; recordings compared between day 1 and some days later may therefore show a significant reduction by chance. However, equivalent reductions in MES following antiplatelet therapy have also been observed in a number of randomized, double-blind, placebo-controlled studies, which strongly suggests that this effect is real. Taken together, these studies provide a sound basis for suggesting that measuring MES frequency might be a good surrogate marker for evaluating the efficacy of antiplatelet agents in the prevention of stroke.

\section{The Future}

While there are now compelling data showing an association of MES with the combined end point of stroke and TIA, equivalent data are not yet available for the end point of stroke alone. For MES to be confirmed as a surrogate marker for stroke, positive results from such studies will be required.

The Clopidogrel plus Aspirin for Infarct Reduction in acute stroke/TIA patients with large artery stenosis and microembolic signal (CLAIR) study will evaluate the effects of clopidogrel in addition to ASA compared with the effects of ASA alone on the incidence of cerebral MES. CLAIR will also look at the correlation between MES and numbers of acute infarct as measured by DWI. This latter investigation has the potential to correlate MES and clinical events using the imaging data.

Together these studies should help to clarify whether cerebral microemboli are sensitive to antiplatelet therapy and whether MES measurements are a reliable surrogate marker of efficacy for evaluation of antiplatelet regimens. CLAIR and other large, ongoing trials will in addition also greatly expand the total patient sample, which is to date still limited.

\section{Conclusions}

From the results of studies to date, there is good evidence to suggest that measurement of MES may be a suitable surrogate marker for evaluating the efficacy of antiplatelet agents in the prevention of stroke, particularly as methods for discriminating between solid and gaseous MES are continually being improved. Studies currently in progress should provide further insight into the value of the measurement of MES in clinical studies in stroke prevention. 


\section{References}

1 Martinez-Vila E, Irimia P: The cost of stroke. Cerebrovasc Dis 2004;17(suppl 1):124-129.

-2 Antithrombotic Trialists' Collaboration: Collaborative meta-analysis of randomised trials of antiplatelet therapy for prevention of death, myocardial infarction, and stroke in high risk patients. BMJ 2002;324:71-86.

3 Forbes CD: Secondary stroke prevention with low-dose aspirin, sustained release dipyridamole alone and in combination. ESPS Investigators. European Stroke Prevention Study. Thromb Res 1998;92(suppl 1):S1-S6.

-4 Gent M, Beaumont D, Blanchard J, Bousser MG, Coffman J, Easton JD, Hampton JR, Harker LA, Janzon L, Kusmierek JJE, Panak E, Roberts RS, Shannon JS, Sicurella J, Tognoni G, Topol EJ, Verstraete M, Warlow C: A randomised, blinded trial of clopidogrel versus aspirin in patients at risk of ischaemic events (CAPRIE). CAPRIE Steering Committee. Lancet 1996;348:1329-1339.

$\rightarrow 5$ Yusuf S, Mehta SR, Zhao F, Gersh BJ, Commerford PJ, Blumenthal M, Budaj A, Wittlinger T, Fox KAA: Early and late effects of clopidogrel in patients with acute coronary syndromes. Circulation 2003;107:966-972.

-6 Steinhubl SR, Berger PB, Mann JTR, Fry ETA, DeLago A, Wilmer C, Topol EJ: Early and sustained dual oral antiplatelet therapy following percutaneous coronary intervention: A randomized controlled trial. JAMA 2002;288: 2411-2420.

7 Nabavi DG, Arato S, Droste DW, Schulte-Altedorneburg G, Kemeny V, Reinecke H, Borggrefe M, Breithardt G, Ringelstein EB: Microembolic load in asymptomatic patients with cardiac aneurysm, severe ventricular dysfunction, and atrial fibrillation. Clinical and hemorheological correlates. Cerebrovasc Dis 1998;8:214-221.

8 Markus H: Monitoring embolism in real time. Circulation 2000;102:826-828.

-9 Kessler CM: Intracerebral platelet accumulation as evidence for embolization of carotid origin. Clin Nucl Med 1992;17:728-729.

10 Markus HS: Transcranial Doppler ultrasound. Br Med Bull 2000;56:378-388.

$\checkmark 11$ Russell D, Madden KP, Clark WM, Sandset PM, Zivin JA: Detection of arterial emboli using Doppler ultrasound in rabbits. Stroke 1991;22:253-258.

-12 Lund C, Braekken SK, Haggag KJ, Roste LS, Russell D: Cerebral microembolism detected by transcranial Doppler ultrasonography (in Norwegian). Tidsskr Nor Laegeforen 1998; 118:1398-1401.
13 Ringelstein EB, Droste DW, Babikian VL, Evans DH, Grosset DG, Kaps M, Markus HS, Russell D, Siebler M: Consensus on microembolus detection by TCD. International Consensus Group on Microembolus Detection. Stroke 1998;29:725-729.

14 Dittrich R, Ritter MA, Droste DW: Microembolus detection by transcranial Doppler sonography. Eur J Ultrasound 2002;16:21-30.

15 Mackinnon AD, Aaslid R, Markus HS: Longterm ambulatory monitoring for cerebral emboli using transcranial Doppler ultrasound. Stroke 2004;35:73-78.

16 Darbellay GA, Duff R, Vesin J-M, Despland P-A, Droste DW, Molina C, Serena J, Sztajzel R, Ruchat P, Karapanayiotides T, Kalangos A, Bogousslavsky J, Ringelstein EB, Devuyst G: Solid or gaseous circulating brain emboli: Are they separable by transcranial ultrasound? J Cereb Blood Flow Metab 2004;24:860-868.

17 Siebler M, Nachtmann A, Sitzer M, Rose G, Kleinschmidt A, Rademacher J, Steinmetz H: Cerebral microembolism and the risk of ischemia in asymptomatic high-grade internal carotid artery stenosis. Stroke 1995;26:21842186.

18 Levi CR, O’Malley HM, Fell G, Roberts AK, Hoare MC, Royle JP, Chan A, Beiles BC, Chambers BR, Bladin CF, Donnan GA: Transcranial Doppler detected cerebral microembolism following carotid endarterectomy. High microembolic signal loads predict postoperative cerebral ischaemia. Brain 1997;120:621629.

19 Valton L, Larrue V, le Traon AP, Massabuau $P$, Geraud G: Microembolic signals and risk of early recurrence in patients with stroke or transient ischemic attack. Stroke 1998;29:21252128.

20 Molloy J, Markus HS: Asymptomatic embolization predicts stroke and TIA risk in patients with carotid artery stenosis. Stroke 1999;30: 1440-1443.

21 Babikian VL, Wijman CA, Hyde C, Cantelmo NL, Winter MR, Baker E, Pochay V: Cerebral microembolism and early recurrent cerebral or retinal ischemic events. Stroke 1997;28:1314 1318.

22 Wong KS, Gao S, Chan YL, Hansberg T, Lam WWM, Droste DW, Kay R, Ringelstein EB: Mechanisms of acute cerebral infarctions in patients with middle cerebral artery stenosis: A diffusion-weighted imaging and microemboli monitoring study. Ann Neurol 2002;52: 74-81.
23 Gao S, Wong KS, Hansberg T, Wynnie WML, Droste DW, Ringelstein EB: Microembolic signal predicts recurrent cerebral ischemic events in acute stroke patients with middle cerebral artery stenosis. Stroke 2004;35:2832-2836.

24 Goertler M, Baeumer M, Kross R, Blaser T, Lutze G, Jost S, Wallesch CW: Rapid decline of cerebral microemboli of arterial origin after intravenous acetylsalicylic acid. Stroke 1999; 30:66-69.

25 Goertler M, Baeumer M, Kross R, Blaser T, Lutze G, Jost S, Wallesch CW: Acetylsalicylic acid and microembolic events detected by transcranial Doppler in symptomatic arterial stenoses. Cerebrovasc Dis 2001;11:324-329.

- 26 Goertler M, Blaser T, Krueger S, Hofmann K, Baeumer M, Wallesch CW: Cessation of embolic signals after antithrombotic prevention is related to reduced risk of recurrent arterioembolic transient ischaemic attack and stroke. $\mathrm{J}$ Neurol Neurosurg Psychiatry 2002;72:338342.

27 Junghans U, Siebler M: Cerebral microembolism is blocked by tirofiban, a selective nonpeptide platelet glycoprotein IIb/IIIa receptor antagonist. Circulation 2003;107:2717-2721.

28 Esagunde RU, Wong KS, Lee MP, Gan HY, Wong MC, Chang HM, Chen CLH: Efficacy of dual anti-platelet therapy in cerebrovascular disease demonstrated by decline in microembolic signals: A report of 8 cases. Cerebrovasc Dis, in press.

29 Payne DA, Jones CI, Hayes PD, Thompson MM, London NJ, Bell PR, Goodall AH, Naylor AR: Beneficial effects of clopidogrel combined with aspirin in reducing cerebral emboli in patients undergoing carotid endarterectomy. Circulation 2004:109:1476-1481.

- 30 Kaposzta Z, Baskerville PA, Madge D, Fraser S, Martin JF, Markus HS: $L$-arginine and Snitrosoglutathione reduce embolization in humans. Circulation 2001;103:2371-2375.

- 31 Kaposzta Z, Clifton A, Molloy J, Martin JF, Markus HS: S-nitrosoglutathione reduces asymptomatic embolization after carotid angioplasty. Circulation 2002;106:3057-3062.

32 Kaposzta Z, Martin JF, Markus HS: Switching off embolization from symptomatic carotid plaque using S-nitrosoglutathione. Circulation 2002;105:1480-1484.

33 Markus HS, Ringelstein EB: The effect of dual antiplatelet therapy compared with aspirin on asymptomatic embolisation in carotid stenosis: The CARESS trial. 13th European Stroke Conference, Mannheim-Heidelberg, 2004, Germany. Abstract available at www.eurostroke.org. 